Dept. of Pathol. (Prof. A. TANAKA), Kyoto. Pref. Med. College, Kawara-machi, Kyoto, Japan.

\title{
Analysis of Cytogenesis in Chick Retina by Tritiated Thymidine Autoradiography.
}

\author{
トリチウムーサイミジンーオートラジオグラフィーによる家鷄 \\ 網膜の細胞発生の分柝.
}

\section{Setsuya FUJITA and Masakiyo HORII}

藤田哲也と堀井正: 清.

(Received April 11, 1963.)

Differentiation of nerve cells and other elements in the developing central nervous system has been studied histologically in materials stained by various techniques especially by silver impregnation. The time sequence of cellular transformation or cytodifferentiation have been deduced from the presence of transitional forms. However, the interpretation of the transitions in structure have always involved some difficulties in the identification of the same cells or the same cell groups in the specimens taken from the successive stages of development, since immature cells are not only lacking in morphologic characteristics but change their shape and localization continuously as they differentiate. In order to reduce the difficulties of the cell identification, vital marking using $\mathrm{H}^{3}$-thymidine has been introduced (MIALE et al. 1961). Tritiated thymidine as specific precursor for deoxyribonucleic acid (DNA) is incorporated rapidly into the cell nucleus which is performing DNA synthesis in preparation for mitosis (HIGHES et al. 1958). Since the DNA is one of the most stable substance in the organism, the $\mathrm{H}^{3}$ thus introduced into the DNA remains as a permanent label unless it is diluted by subsequent mitoses and the label can be detected by autoradiographic procedure with satisfactory resolution so that the labeled nucleus can be distinguished from the unlabeled with certainty. Therefore, by introducing the label into the selected cell groups and tracing them, one can follow the fate of the cell.

Histogentic analysis of the central nervous system using $\mathrm{H}^{3}$-thymidine autoradiography has been reported by previous investigators (UZMAN 1960, MIALE et al. 1961, SIDMAN 1961). They used mice and gave a single injection of the $\mathrm{H}^{3}$-thymidine into the pregnant animals, in which the label is decomposed quickly and remains in the available concentration only for a few hours. Therefore, even at the time of the maximal labeling, the majority of the cells in the neural tube of the fetal mice have not taken the label. And the radioactivity in the labeled matrix cells is not uniformly distributed but shows marked variety in intensity, since the cells that were synthesizing DNA all the time during which the $\mathrm{H}^{3}$-thymidine was available have taken the label fully and are labeled most intensely, while the cells that were going to finish DNA synihesis at the time of the injection, or the cells that had just entered the period of DNA synthesis at the time the $\mathrm{H}^{3}$-thymidine became no more available have 
taken little or, if any, very weak labeling. Thus the matrix cells, homogeneous ir nature, become labeled with a varying density of radioactivity from zero to the maximal labeling. In the course of time, neuroblast which are differentiated from these matrix cells possess the radioactivity with all the possible variations in intensity; even in the group of the neuroblasts produced at the same generation of the matrix cells some are labeled and some are unlabeled. As the gnerations of the matrix cells proceed, the label shared in the neuroblasts from the labeled matrix cells is reduced and finally lost (FUJITA $1962 \mathrm{~b}$ ). Thus the presence of the radioactivity and its intensity in the nuclei of the neuroblasts depend upon several complicated factors. Therefore, the presence of neurons devoid of the label among the labeled ones, may be interpreted by the following alternatives. 1 . The neurons may have been produced before the $\mathrm{H}^{3}$-thymidine is injected, 2. the neuroblasts may be produced far later than the injection of the label so that the radioactivity in the matrix cells has been diluted by their successive divisions and finally lost from them when they differentiate into the neuroblasts, or 3. the matrix cells from which the neurons are derived happened to be in the intersynthetic period when the $\mathrm{H}^{3}$-thymidine was available. Concerning the radioactive neurons, it may be right to conclude that they are produced later than the injection of the label and before the label finally disappears from the matrix cells. However, it is still impossible to determine the date of the beginning of the neuron producation by this method, because the injection of the $\mathrm{H}^{3}$-thymidine on any day before the neuroblast production results in an essentially similar pattern of neuroblast labeling; if a neural tube is flash-labeled on one day of the embryonic days before the production of those neuroblasts begins, a part of the matrix cells take the label at that time and produce some radioactive neurons continuously until the label is diluted and finally lost from their nuclei. Suppose we inject the label one day earlier and the label is incorporated by a part of the matrix cells heavily enough to be kept until the day on which those neuroblasts are produced from them, a part of the neuroblasts will be found radioactive. Here the possible difference can only be present in the density of the label in those neuroblasts. However, as stated above, the density of the radioactivity in the flashlabeled autoradiographs shows all the possible variation even in a single neuroblast group produced at the same generation. The correct interpretation of the results is, therefore, very difficult and virtually impossible. On the other hand, by the cumulative labeling method (FUJITA 1963a, 1963 b), the initial labeling of the matrix cells is uniform. Therefore, the group of neuroblasts produced at the same generation of the matrix cells is uniformly labeled as their direct predecessor matrix cells. Thus, tracing the migration and metamorphosis of the labeled and the unlabeled neuroblasts we can study the mode of cytodifferentiation in finer detail. By the cumulative labeling technique, the presence of even a single unlabeled neuroblast of the group can be interpreted correctly.

\section{Materials and Methods.}

Nine groups, of which each is consisting of 12 white leghorn chick embryos, were injected with $25 \mu \mathrm{C}$ of $\mathrm{H}^{-}{ }^{3}$ thymidine (specific activity : $4.23 \mathrm{C} / \mathrm{mM}$ ) on $3,4,5,6,6.5$, $7,8,9$ or 10 days of incubation respectively. The embryos of each group were killed 
after 30 minutes, 10 hours, $1,2,3,4,5,6,7,8$, and 9 days and at the time of hatching respectively. The head of each embryo was fixed in CARNOY's solution, embedded in paraffin and cut horizontally in serial section. The autoradiographs were prepared by usual stripping invert method with FUJI ET-2E stripping type film. The exposure was 30 days.

\section{Observations.}

In common with the other portions of the neural tube, the optic part of the retinal anlage of early embryonic days is solely composed of the matrix cells (FUJITA 1962a). The autoradiographs taken shortly after the $\mathrm{H}^{3}$-thymidine injection (flash labeling autoradiograph) showed radioactive nuclei virtually restricted to the S-zone of the matrix layer (Fig. 1). This is completely the same as has been observed throughout the neural tube. The labeled cells in the matrix layer increased in number with time and got to $100 \%$ after 10 hours. The mode of the increase of the labeled cells, is the same as described with the mesencephalon, spinal cord and cerebellum (FUJITA 1963a).

Concerning the description 'external' or 'internal' about the retina a comment may be necessary since the internal limiting membrane beneath which the matrix cells perform their mitoses turns to the outside in the retina vis a-vis with the choroid epithelium. In the usual terminology of the eye, this membrane has been called external limiting membrane, in contrast with the designation in the neural tube. But the authors call it in this paper 'internal' limiting membrane since it is a continuous structure with the internal limiting membrane of the neural tube. This designation adopted here is more natural when the retina is considered as a part of the neural tube.

In the most external zone of the retina, a layer of unlabeled cells with rounded larger nuclei appeared during the 5th day of incubation, in the flash labeling autoradiograph (Fig. 1). It is the mantle layer consisting of the neuroblasts. It appeared at the most medial pole (cf. Fig. 5) at the time. In the portion of the equator of the eye ball, the matrix layer of the retina stretched from the internal to the external limiting membrane and the mantle layer did not appear yet. In the chick embryo which had received the injection of $\mathbf{H}^{3}$-thymidine at the beginning of the 5th day and was killed 24 hours later, all the matrix cells and the neuroblasts showed dense and uniform labeling (Fig. 2). This finding indicates that the neuroblast accumulating in the mantle layer of the medial pole have been produced during the 5 th day of incubation. They develop to the neurons in the ganglionic layer in the fully developed retina as discussed in the next section.

The distribution of the labeled cells in more advanced stages of development.

In the newly hatched chick which had received the injection of the label at the beginning of the 4 th day of incubtaion, all the neurons in the ganglionic layers were radioactive, though weakly, while the $\mathrm{H}^{3}$-thymidine given on the 5 th day or the 6 th day of incubation could not label some neurons in the ganglionic layer in the medial pole. These findings are interpreted as follows. The matrix cells destined for the ganglionic cells partially finish their final DNA synthesis earliest at the medial pole 


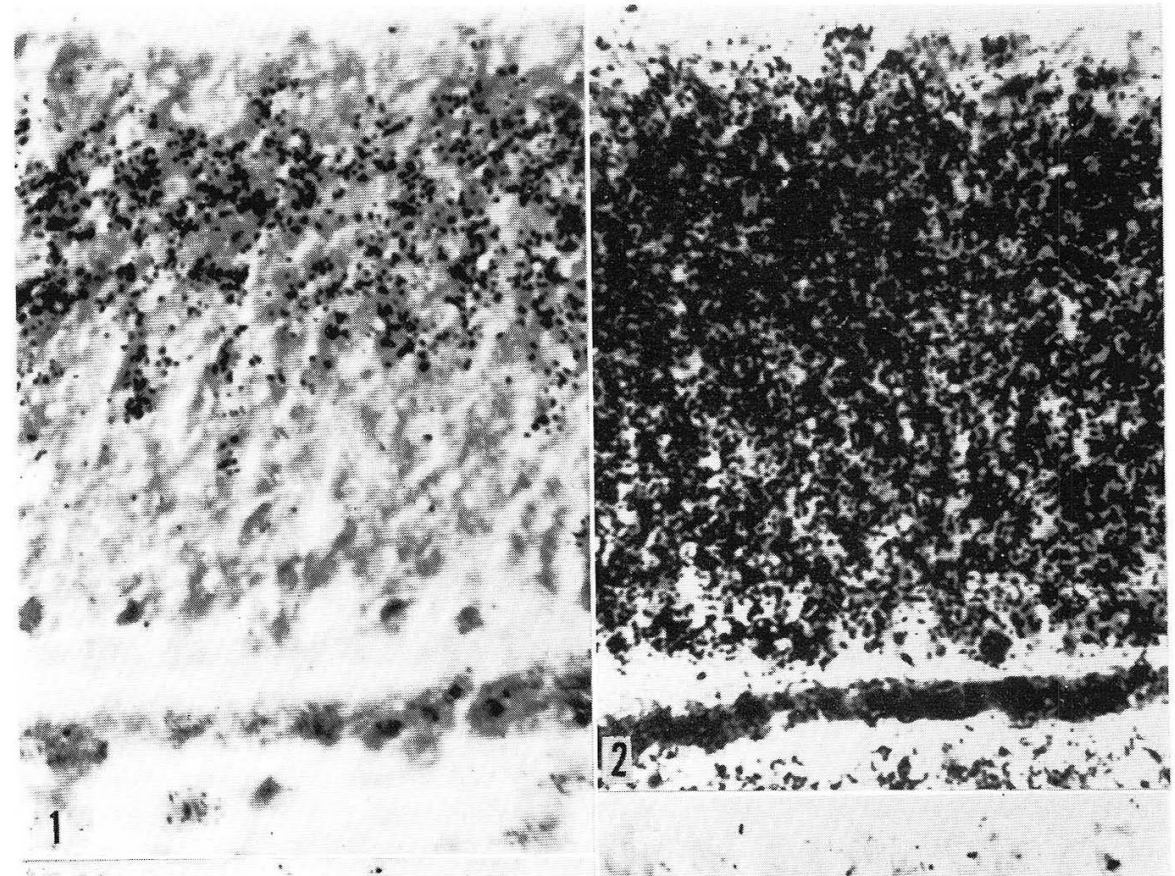

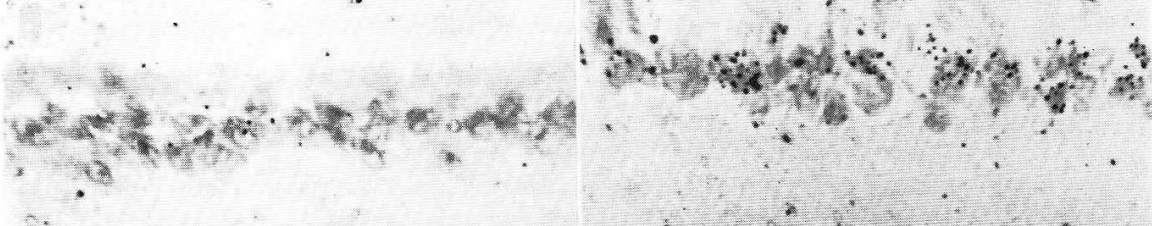

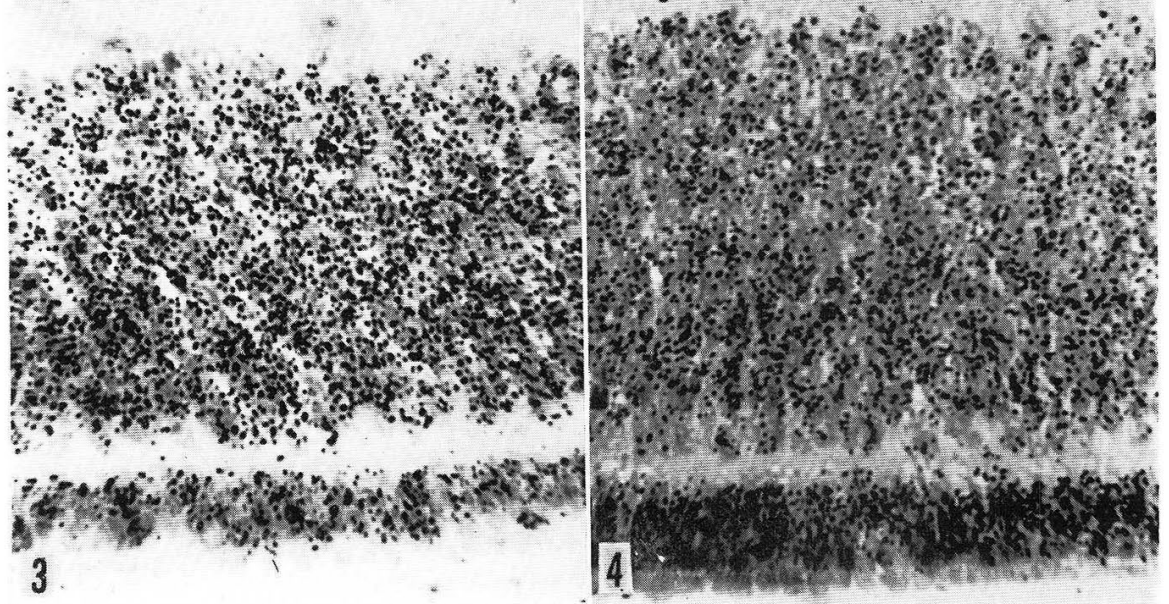


of the retina already on the 5th day of incubation. In the retina of the hatched chick which had been injected with the label at the beginning of 7 th day of incubation, many neurons in the ganglionic layer in the medial zone and medial pole were found to be free from the radioactivity while most of them in the lateral zone have taken the label. The photoreceptor cells in the visual cell layer as well as cells in the bipolar cell layer were labeled weakly but uniformly throughout the retina. In the chick embryo which had been injected with the $\mathrm{H}^{3}$-thymidine at the beginning of the 7.5 th day of incubation and sacrificed 6 days later, most neurons were found unlabeled in the medial pole of the retina except a few weakly labeled ones but here the visual cells were labeled fairly densely (Fig. 3). The labeled neurons in the ganglionic layer gradually increased in numbe and in density of the labeling, as we scanned the retina toward the equator (Fig. 4). These findings indicate that the tide of the neuron differentiation spreads from the medial pole over the equator toward the ora serrata, so that the neurons located more laterally are produced later than those in the medial portion. The labeling of the visual cell layer also showed the same tendency for variation owing to the localization but the site of the weakest labeling was situated just rostro-cranial to the pecten of the eye (the dotted area in Fig. 5). In the portion around the equator and in the lateral zone, the 3 layers became commonly labeled fairly densely. The distribution of the silver grains was quite uniform both in the bipolar and visual cell layers but some neurons in the ganglionic layer were still unlabeled (Fig. 4). And the density of the label was highest in the cells of the visual cell layer in the lateral zone of the eye. In the retina of newly hatched chick which received the injection of the label on the 8th day of incubation, a small portion of the neurons in the ganglionic layer were found to be radioactive in the lateral and medial zones but none in the medial pole. And finally no neurons bec me labeled in the newly hatched chick which had received the $\mathrm{H}^{3}$-thymidine injection at the beginnig of the 9 th day of incubation. In this retina weak labeling was detected in the visual cell layer of the lateral zone of the eye especially near to the ora serrata and in the bipolar cell layer throughout the retina.

Fig. 1-2. Autoradiographs of the retina from the chick embryo of 5 days of incubation.

Fig. 1 Thirty minutes after the injection of $\mathrm{H}^{3}$-thymidine. The label is restricted to the $\mathrm{S}$ zone of the matrix layer. No cells in the M- and I-zones have taken the label. Note that the neuroblasts accumulating in the mantle layer are also unlabeled. $\times 550$

Fig. 2. The corresponding portion of the retina of a chick embryo of the same age as in Fig. 1 which received the injection of $\mathrm{H}^{3}$-thymidine 24 hours prior to sacrifice. All the matrix cells as well as the neuroblasts in the mantle layer have incorporated the label. $\times 550$

Fig. 3-4. Autoradiographs of the retina from the 13 day-old chick embryo which received the injection of $\mathrm{H}^{3}$-thymidine at the beginning of the 7.5 th day of incubation.

Fig. 3. The retina from the medial pole of the eye. A few neurons in the ganglionic layer is found weakly radioactive but most of them are free from the radioactivity. Many cells in the visual cell layer show moderate labeling. Bipolar cell layer is also found uniformly radioactive. $\times 550$

Fig. 4. The retina of the same eye, from the lateral zone. Many cells in the ganglionic layer are labeled relatively heavily and some negative neurons are scattered among them. The radioactivity in the visual cell layer still increases in this portion as compared with the Fig. 3. The labeling of the bipolar cell layer is also uniform and dense. $\times 550$ 


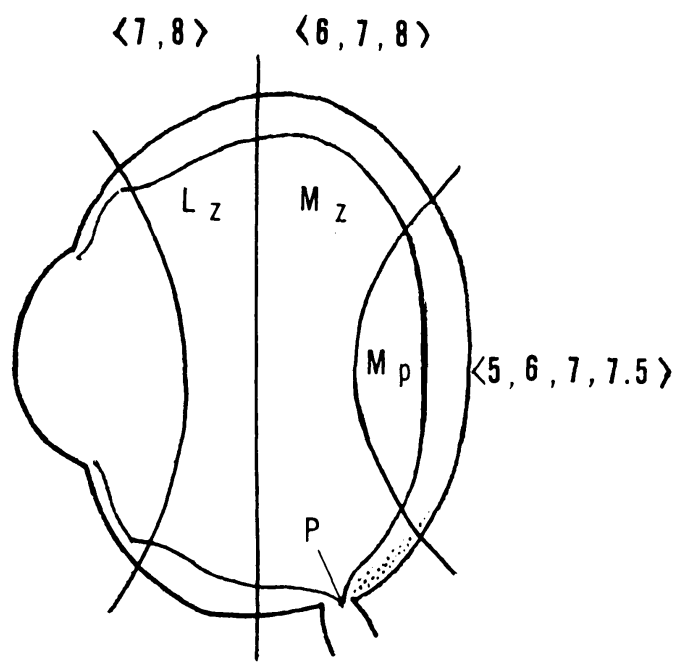

Fig. 5. Schematic drawing of the eye cut in horizontal section. $L z$ indicates lateral zone, $M z$ medical zone, $M p$ medial pole, $p$ pecten of the eye. The bracket in each compartment shows the date of neuron production in the respective portion of the ganglionic layer; e. g. $\langle 7,8\rangle$ indicates that the neurons in this portion are produced during the 7 th and 8 th days of incubation, etc.

\section{Disussion.}

Concerning the patterns of the labeling in the visual cells, the following two alternative interpretations seem to be possible: 1 . similar to the neurons in the ganglionic layer, the visual cells perform their final DNA synthesis a little later to that of the ganglionic cells, so that the distribution of the radioactivity was qualitatively similar to that in the ganglionic layer, or 2 . on the contrary. the visual cells remain mitotically active beyond the time at which all the ganglionic cells have differentiated, so that the label once incorporated in the visual cell nuclei is subjected to the dilution by their successive divisions and finally lost from the nuclei. The fact that the mitotic figures are found in the visual cell layer until the 15th day of incubation (MOOG 1958) seems to favor the second interpretation. However, this view is unlikely since the label injected on the 5th day of incubation is found in the visual layer of the medial pole even on the day of hatching while that injected on the 8th day of incubation fails to label the visual cells of the same region in the newly hatched chick. This observation is hardly compatible with the second interpretation. Therefore, it is concluded that the visual cells in the medial pole perform their final DNA synthesis later than the 5th day but finish it before the 8th diy of incubation. The mitotic figures found in this portion of the visual cell layer during the second week of incubation, therefore, must be explained by the 'elevator movement' (FUJITA 1963a) of the cells in the bipolar cell layer, though it begins to be separated from the visual cell layer by the outer plexiform layer; the cell in the bipolar cell layer ascends toward the internal limiting membrane passing through the plexiform layer as it has finished DNA synthesis, divides directly beneath the internal limiting membrane (among the visual cells) and descends again toward the bipolar cell layer when it goes through the mitosis. This up and down movement of the cells in the bipolar cell layer, similar to that of the matrix cells has been pointed out by SIDMAN (1961) with observations 
on the embryonic retina of the mouse. Thus it is concluded that, in the retina, the matrix cells first differentiate ganglionic cells which accumulate externally, and secondly produce the visual cells which are shifted toward the internal limiting membrane, while the matrix cells still proliferate performing the elevator movement between the bipolar cell layer and internal limiting membrane. The dat?s of neuron differentiation in the ganglionic layers is shown in Fig. 5 . The visual cells seem to differentiate first at the region near the pecten (Fig. 5, the dotted area) a little later to the ganglionic cells, presumably one day later. The cells in the bipolar cell layer develop lastly, in which some remain capable of DNA synthesis yet on the day of hatching. Since, however, there are various types of cells in the bipolar cell layer (such as bipolar cells, amacrine cells, horizontal cells, MÜLLER's cells and so on), one should count the labeling of the types of cell separately in order to interpret the findings correctly. In the present study, therefore, it is impossible to draw any definite conclusion for the cells in this layer since the data are obtained from the mixed cell population. To eliminate the obscurity, one should have applied specific staining to differentiate cell types in the autoradiography and counted the labeled cells separately for every type of cell.

\section{Summary.}

Using cumulative labeling method, cytogenesis of chick retina was studied by $\mathrm{H}^{3}$-thymidine autoradiography and the followings were concluded.

The first to differentiate in the optic retina are the neurons in the ganglionic layer. The process of differentiation begins at the medial pole on the 5 th day of incubation and spreads toward the ora serrata, taking 2 days. The cells in the visual cell layer are differentiated a little later, probably by one day, than the ganglionic cells. This process first takes place in the region near the pecten of the eye and gradually spreads toward the medial pole and then to the periphery. Most mitotic figures found during the second week of incubation in the visual cell layer seem to belong to the matrix cells in the bipolar cell layer.

\section{内 容 自 抄.}

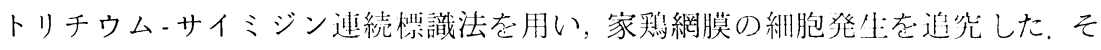
の絬果を要約すると以下の如くである。

網膜で最初に分化してくるのは神経細胞層のニューロンであり，乙の過程は睬 卵第 5 日に眼球の内側極加ら始まってくる．分化の波はここから鋸状縁の方へ約 2 日かかって搪がる。視覚細胞分化はこれに約 1 日ほど羊れて櫛に㑕した部分か ら始まり，初め内側極の力へ，次いで周辺部へ波及す万，洏極紃胞層の絒胞は最

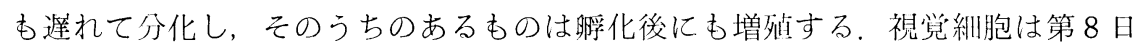
以後急速にその分裂能を失うので，睬卵第 2 週にみられる視覚細胞層の分裂像の 多くは両極絸胞層の母基絒胞がエレベーター連動を行なった結果ここに现れたも のと考えられる。 


\section{References.}

Fujita, S.: Exptl. Cell Res. 28 (1962a). P. 52. - Exptl. Cell Res. 28 (1962b). P. 158. J. comp. Neurol. 120 (1963a). P. 37. - J. comp. Neurol. in press (1963 b). - Hughes, W. L. et al.: Proc. Nat. Acad. Sc. 44 (1958). P. 476. - Miale, I. L. and R. L. Sidman: Exptl. Neurol. 4 (1961). P. 277. - Moog,F.: The Cytodifferentiation. Edited by D. Rudnick. Univ. of Chicago Press. 1958. P. 34. - Sidman, R. L.: The Structure of the Eye. Edited by G. K. Smelser. Academic Press, New York. 1961. P. 487. - Uzman, L. L.: J. comp. Neurol., 114 (1960). P. 137. 